\title{
Sessiz mastoidit: İki olgu sunumu
}

\section{Silent mastoiditis: Two case reports}

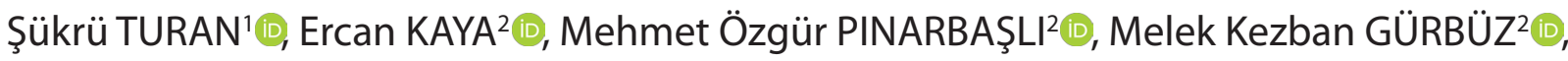 Şaziye Armağan iNCESULU² $\square$}

'Çorum Sungurlu Devlet Hastanesi, Kulak Burun Boğaz Kliniği, Çorum/TÜRKiYE

${ }^{2}$ Osmangazi Üniversitesi Tıp Fakültesi Hastanesi, Kulak Burun Boğaz ABD, Eskişehir/TÜRKiYE

\section{öz}

Sessiz mastoidit mastoid hücrelerin kemik yapılarında ve mukozal tabakadaki subklinik enfeksiyöz enflamatuar süreci tanımlamaktadır. Hayatının belli döneminde akut otitis media (AOM) geçiren ve yanlış antibiyotik tercihi veya yetersiz dozda antibiyotik kullanımı sonucunda hastaların kliniğinde gerileme olmasına rağmen; bakterilerin eredike olmaması sonucunda sessiz mastoidit gelişmektedir. Bu hastaların kliniğinde genellikle hiçbir semptom olmamakla birlikte bazı hastalarda baş ağrısıyla karışan kulak ağrısı, mastoid bölgede duyarlılık, işitme kaybı, kulakta dolgunluk hissi ve subfebril ateş gibi semptomlar olabilmektedir. Sessiz mastoidit subklinik seyirli olması ve fizik muayenede tipik bulgusunun olmaması sebebiyle gözden kaçmakta ve hastalarda yaşam kalitesini bozan şikayetler oluşturmaktadır. Bu çalışmadaki amacımız kliniğimizde sessiz mastoidit tanısı konularak tedavileri gerçekleştirilen iki olgunun literatür eşliğinde tartışılması ve sessiz mastoiditin öneminin vurgulanmasıdır.

Anahtar kelimeler: maskelenmiş mastoidit; mastoidektomi; otitis media; sessiz mastoidit; sintigrafi

\section{ABSTRACT}

Silent mastoiditis describes the subclinical infectious inflammatory process in the bone structures of the mastoid cells and the mucosal layer. In the diagnosis of acute otitis media (AOM), despite the decrease in the the patients' clinic status, as a result of the wrong antibiotic preference or inadequate dose of antibiotics, silent mastoiditis develops due to the fact that the bacteria are not eradicated.Although there are usually no symptoms in these patients, some patients may have symptoms such as ear pain feeling like headache, sensitivity in mastoid region, hearing loss, ear fullness and subfebrile fever. Silent mastoiditis is overlooked because of its subclinical course and the lack of typical findings in physical examination. and causes complaints that impair quality of life in patients. The aim of this study is to emphasize the importance of silent mastoiditis and discuss, two cases of silent mastoiditis which diagnosed and treated in our clinic,with the literature.

Keywords: masked mastoiditis; mastoidectomy; otitis media; silent mastoiditis; scintigraphy

Sorumlu Yazara: Şükrü Turan, Çorum Sungurlu Devlet Hastanesi, Kulak Burun Boğaz Kliniği, Çorum/TÜRKiYE E-mail: drsukruturan@gmail.com

ORCID: 0000-0001-9215-301X

Gönderim:13.12.2018 Kabul: 09.02.2019

Doi: $10.18663 / \mathrm{tjcl} .496994$ 


\section{Giriş}

Antibiyotik öncesi dönemde akut otitis media olgularında akut mastoidit ve akut mastoidite bağlı gelişen intrakranial komplikasyonlar sık görülürdü [1]. Günümüzde geniş spektrumlu antibiyotik kullanımının yaygın olmasına bağlı olarak klasik mastoidit sıklığı giderek azalmıştır. Klasik mastoidit yerine subklinik seyrederek gözden kaçabilen ve ciddi komplikasyonlar yaratabilen sessiz mastoidit sıklığı artmıştır [2]. Sessiz mastoidit; mastoid hücrelerin kemik yapılarında ve mukozal tabakalarındaki subklinik enflamatuar süreci tanımlamaktadır [3]. Sessiz mastoiditte orta kulak boşluğu sağlıklıdır [4]. Literatürde latent mastoidit ve maskelenmiş mastoidit olarak da adlandırılmaktadır $[3,5]$. Sessiz mastoidit ciddi otojenik komplikasyonlar oluşturma potansiyeli nedeniyle erken tanı konulmalı ve geciktirilmeden tedavi edilmelidir [4].

Bu çalışmadaki amacımız kliniğimizde sessiz mastoidit tanısı konularak tedavileri yapılan iki olguyu literatür eşliğinde tartışarak sessiz mastoidit'in önemini vurgulamaktır.

\section{Olgu 1}

Otuz sekiz yaşında kadın hasta; polikliniğimize yaklaşık on aydır başın sağ yarımında ağrı ve yine aynı bölgede son yirmi gündür süren uyuşukluk şikayetiyle başvurdu. Hastanın yaklaşık bir yıl önce sağ akut otitis media nedenli dış merkezde antibiyotik tedavisi aldığı ve şikayetlerinin gerilediği öğrenildi. Bu enfeksiyon sonrasında aynı kulağında hafif bir işitme kaybı şikayeti de başlamış. Özgeçmişinde üç yıldır hipertansiyon nedenli ilaç kullanım öyküsü ve üç kez sezeryan öyküsü mevcuttu. Hastanın yapılan kulak burun boğaz fizik muayenesinde patolojik bulguya rastlanmadı. Yapılan odyometrik incelemede sağ kulakta hafif derecede iletim tipi işitme kaybı mevcuttu. Bu bulgularla hastadan temporal kemik bilgisayarlı tomografisi (BT) ve difüzyonlu temporal kemik manyetik rezonans görüntüleme (MRG) yöntemi istendi. Temporal kemik BT'sinde mastoid antrum ve mastoid hücrelere uzanan yumuşak doku değerleri izlendi (Resim 1). Temporal kemik MRG'de difüzyon kısıtlanması göstermeyen mastoid antrum ve mastoid hücrelere uzanan yumuşak dokular izlendi. Öykü, fizik muayene ve radyolojik tetkikler sonucunda ön tanı olarak sessiz mastoidit'ten şüphelenilen hastadan üç fazlı kemik sintigrafisi istendi. Teknesyum-99 (Tc99m) ile yapılan sintigrafik incelemede üçüncü saatteki görüntülerde sağ mastoid bölgede sol mastoid bölgeye göre artmış tutulum saptandı. Bu bulgularla hastaya genel anestezi altında sağ kortikal mastoidektomi yapıldı. Operasyon esnasında mastoid kavite içerisinde granülasyon dokularına rastlandı. Postoperatif takiplerinde şikayetlerinde tamamen düzelme olan hasta takibimize alındı.

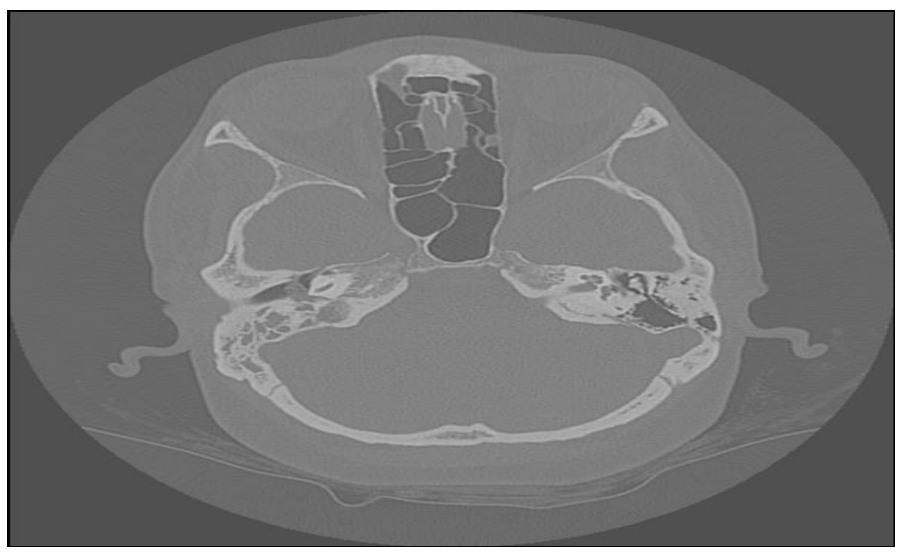

Resim 1: Birinci olgunun Temporal BT'sinde mastoid antrum ve mastoid hücrelere uzanan yumuşak doku değerleri

\section{Olgu 2}

Otuz yaşında kadın hasta; dört ay önce üst solunum yolu enfeksiyonu sonrasında sağ kulağında ağrı şikayeti olması üzerine dış merkeze başvurmuş. Dış merkezde üst solunum yoluna ikincil gelişen sağ akut otitis media tanısı konularak medikal tedavi başlanmış ve medikal tedavi sonrasında hastanın sağ kulak ağrısı gerilemiş. Hasta kulak ağrısı gerilediği için antibiyotik tedavisini tamamen bitirmediğini belirtiyor. Medikal tedavi bitiminden iki hafta sonra sağ kulak ağrısı tekrar başlayan hastanın yine aynı kulağından üç gün boyunca kanlı kulak akıntısı olmuş. Akıntı sonrasında sağ kulağında işitme kaybı da başlamış. Bu şikayetlerle dış merkeze başvuran hastaya lokal anestezi altında sağ ventilasyon tüpü tatbiki yapılmış. Operasyondan sonra sağ kulak bölgesinde ve çevresinde zonklayıcı tarzda baş ağrısı azalan ancak tamamen geçmeyen hasta kliniğimize başvurdu. Hastanın yapılan kulak burun boğaz fizik muayenesinde sağ dış kulak yolunda ventilasyon tüpü mevcuttu ve ventilasyon tüpü mikroskop altında poliklinik şartlarında çıkarıldı. Her iki timpanik membran intakt olarak izlendi. Sağ mastoid kemik üzerinde palpasyonla hassasiyeti mevcuttu. Yapılan odyometrik incelemede her iki kulakta anormal bulguya rastlanmadı. Hasta kliniğimize yatırılarak intravenöz anaerop ve aerop etkili antibiyoterapi tedavisine başlandı. Hastanın Temporal kemik BT' sinde sağ mastoid bölgede yumuşak doku yoğunluğu saptandı (Resim 2). Difüzyon temporal kemik MRG'de sağ mastoid bölgede difüzyon kısıtlamayan yumuşak doku yoğunluğu izlendi. Klinik değerlendirme sonucunda ön tanı olarak sessiz mastoidit düşünülen hastadan üç fazlı kemik sintigrafisi istendi. Teknesyum-99 (Tc99m) ile yapılan sintigrafik incelemede üçüncü saatte (geç metabolik fazda) alınan görüntülerde sağ mastoid bölgede sol mastoid bölgeye göre osteoblastik aktivite artışı ile uyumlu görünüm saptandı. Sessiz mastoidit tanısı konulan hastaya genel anestezi altında sağ kortikal mastoidektomi yapıldı. Operasyon esnasında mastoid kavite içerisinde 
granülasyon ve yumuşak dokulara rastlandı. Mastoid hücreler arası kemik dokunun yumuşaklığı da dikkati çekmiştir. Operasyon sonrasında ve kontrol muayenelerinde ağrı şikayeti gerileyen hasta takibe alındı. Çalışma için yerel etik kurul onayı alındı. Hasta onam formları imzalatıldı.

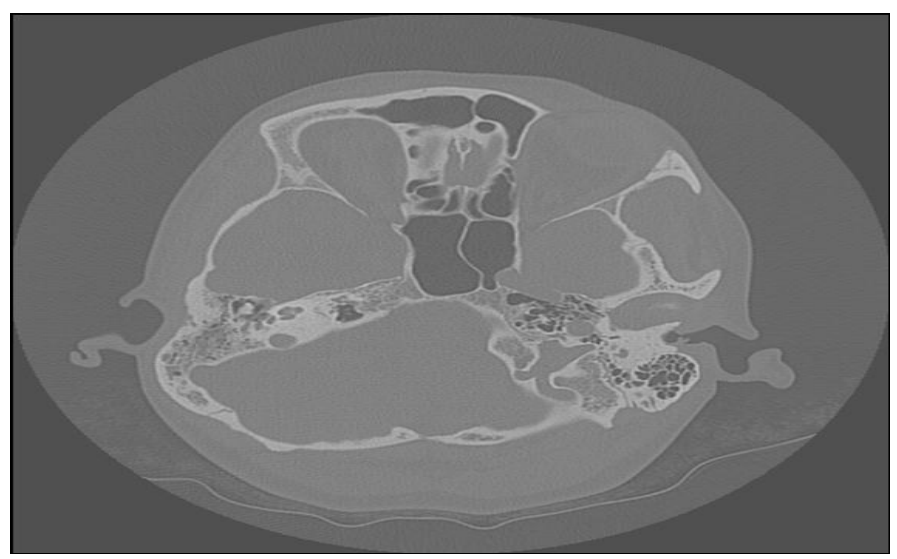

Resim 2 : İkinci olgunun Temporal BT' sinde sağ mastoid bölgede yumuşak doku yoğunluğu değerleri

\section{Tartışma}

Sessiz mastoidit genellikle akut otitis media sonrasında meydana gelen nadir görülen klinik bir tablodur. Akut otitis media tedavisinde yanlış antibiyotik seçimi veya doğru antibiyotik seçimine rağmen yetersiz dozda antibiyotik kullanımı sonrasında hastaların şikayetlerinde gerileme olur ancak bakterilerin tam eredike edilememesi sonucu mastoid kemik ve mukozal dokularda subklinik inflamatuar tablo devam eder $[3,5,6]$. Sessiz mastoidit subklinik seyirli olması ve fizik muayenede tipik bulgusunun olmaması sebebiyle gözden kaçmakta ve hastalarda yaşam kalitesini bozan şikayetler oluşturmaktadır.

Sessiz mastoidit'in klinik önemi ilk defa Amerika Birleşik Devletleri'nde ortaya çıkan Neisseria menenjiti salgını sonrasında ortaya çıkmıştır. Menenjit nedeniyleölen çocukların otopsilerinde; menenjit kaynağının orta kulak ve mastoid içerisinde olduğu histopatolojik çalışmalar sonrasında kanıtlanmıştır. 1963 yılında Mawson ve 1979 yılında Goodhill akut otitis mediada antibiyotik kullanımı sonrasında yeni bir komplikasyon sürecinin ortaya çıktığını bildirmişlerdir [6].

Sessiz mastoidit olgularında klinik olarak hiçbir semptom olmayabilir. Semptomatik olgularda işitme kaybı, baş ağrısı ile karışan kulak ağrısı, kulakta dolgunluk hissi, hafif ateş ve kulak arkasında hassasiyet görülebilir $[1,3,6]$. Çocuk olgularda ise iştah kaybı, halsizlik, kronik ya da rekurren ateş gibi nonspesifik semptomlar görülür [3]. Komplikasyon gelişen olgularda ise ciddi kulak ve baş ağrıları, çınlama, bulantı, kusma, baş dönmesi, titreme, ateş ve meningeal irritasyon bulguları gibi şikayetler görülebilir [3]. Sunduğumuz olgularda kulak ağrısı şikayeti ön plandaydı. Illk olguda kulak ağrısına ek olarak hafif derecede işitme kaybı şikayeti de mevcuttu.
Sessiz mastoidit olgularının özgeçmişinde genellikle geçirilmiş akut otitis media öyküsü mevcuttur [3,6]. Bu enfeksiyon sırasında yanlış antibiyotik seçimi, doğru ancak yetersiz dozda antibiyotik kullanımı veya bakteriyel dirence bağlı olarak bakteriler tam olarak eredike edilemez. Ancak olguların otitis media'ya bağlı gelişen akut klinik şikayetleri geriler [3,5]. Bu olgularda AOM’nın gerilemiş olduğu kabul edildiği için olgular intratemporal veya intrakranial komplikasyonlar gelişene kadar gözden kaçarlar veya hasta olarak kabul edilmezler [6]. Tam eredike edilemeyen bakteriler mastoid mukozası ve kemik dokularda varlığını sürdürmekte ve bu dokularda histopatolojik değişikliklere neden olmaktadır [6]. Mastoid kavite içerisinde inflamatuar reaksiyon, granülasyon dokusu, osteit ve ilerleyen dönemde osteolizis gibi histolojik değişikliler devam etmektedir [3,6]. Sonuç olarak patogenez oluşum mekanizmasında yetersiz tedavi edilen AOM sonucu mukozal ödem ve granülasyon dokusu oluşumuna inanılmaktadır [4]. Çalışmamızdaki her iki olgunun da daha önceden geçirilmiş AOM öyküsü mevcuttur. İkinci olgunun yetersiz dozda antibiyotik kullanım öyküsü de mevcuttur.

Sessiz mastoidit tanısı dikkatli ve ayrıntılı bir anamnez, ayrıntılı otolojik muayene ve radyolojik yöntemlerle konulabilir [5]. Anamnezde daha önceden geçirilmiş ve yetersiz tedavi alınmış AOM öyküsü sorgulanmalıdır. Kulak burun boğaz fizik muayenesinde çoğunlukla timpanik membran intakt olarak saptanır. Bazen timpanik membranda kalınlaşma, pars fleksida bölgesinde lokalize hiperemi, mastoid kemik üzerinde palpasyonla hassasiyet saptanabilir [5]. Sessiz mastoidit olgularında radyolojik yöntemler tanıda önemlidir. Temporal kemiğin Bilgisayarlı Tomografi (BT)ile görüntülenmesinde mastoid hücrelerde havalanma kaybı, mastoid hücre aralığında kemik doku artışı, attik ve mastoid bölgelerde yumuşak doku artışı görülmektedir [6]. Ancak bu bulgular sessiz mastoidite özgü değildir. Bilgisayarlı Tomografide osteolizisin gösterilebilmesi için kemik matriksin \%30-50 oranında tahrip olması gereklidir [7]. Bu durum sessiz mastoidit olgularında tanıda gecikme yaratabilir. Bilgisayarlı Tomografinin sessiz mastoidit tanısı açısından dezavantajı budur. Teknesyum-99 ile yapılan sintigrafik çalışmalar tanıda önemlidir. Teknesyum-99 yeni kemik oluşumu olan dokularda tutulan bir maddedir. Enfeksiyona bağlı gelişen yeni kemik oluşumunda ise Tc99m normale göre \%15 daha fazla tutulmaktadır [6,7]. Bu tutulum sayesinde kemik dokulardaki artmış osteoblastik aktivite saptanmaktadır. Çalışmamızdaki olgularda patolojik fizik muayene bulgusu olarak sadece ikinci olguda sağ mastoid kemikte palpasyonla hassasiyet saptanmıştır. Her iki olgunun temporal kemik BT'nde mastoid bölgede yumuşak dokular saptanmıştır. Her iki olguda da Tc99m ile yapılan sintigrafik incelemelerde patolojinin 
olduğu mastoid kemikte geç fazda artmış osteoblastik aktivite saptanmıştır. Teknesyum-99 ile yapılan sintigrafik çalışmalar günlük pratikte rutin olarak yapılan tetkikler değildir. Sessiz mastoidit şüphesi olan olgularda mutlaka istenmeli; özellikle geç metabolik faz değerlendirilmelidir.

Sessiz mastoidit ciddi otojenik komplikasyonlar oluşturma potansiyeli nedeniyle erken tanı konulmalı ve geciktirilmeden tedavi edilmelidir [4]. Sessiz mastoidit olgularında öncelikle aerobik ve anaerobik etkili intravenöz antibiyotik tedavisi başlanmalıdır [6]. Sessiz mastoidit olgularının tedavisinde mastoidektominin mutlak gerekli olduğu ve zamanlama olarak genel durumu müsait olunan en kısa sürede cerrahi işlem yapılmalıdır [3,5]. Komplikasyon gelişen olgularda ise komplikasyonlara yönelik tedaviler ve sessiz mastoidite yönelik cerrahi tedavi uygulanmalıdır.

Tedavi edilmeyen sessiz mastoidit olgularında ağrı, ateş, kulak akıntısı gibi uyarıcı semptom ve bulgular olmadan bile hayatı tehdit edici ciddi komplikasyonlar gelişebilir [5]. İntrakraniyal komplikasyonlar menenjit, beyin absesi, lateral sinüs tromboflebiti, kortikal sinüslerde tıkanma ve ensefalittir [6]. Sessiz mastoiditte intrakranial komplikasyonlar çoğunlukla tek bir odak halinde görülürken, literatürde multiple intrakranial komplikasyonla seyreden sessiz mastoidit olguları da bildirilmiştir [4]. İntratemporal komplikasyonlar ise sensörinöral tip işitme kaybı, fasial paralizi ve tinnitustur [6]. Çalışmamızdaki olgularda klinik ve radyolojik incelemelerde komplikayon bulgularına rastlanmamıştır.

\section{Sonuç}

Akut otitis media tanısı konulan hastalara doğru ve etkin antibiyoterapi başlanılmalı ve hastalara antibiyotikleri düzenli kullanmaları gerektiği özellikle belirtilmelidir. Takiplerinde işitme kaybı, hafif kulak ağrısı, kulakta dolgunluk hissi, kulak arkasında duyarlılık gibi belirgin olmayan kulak şikayetleri devam eden hastalarda, ciddi komplikasyonlar oluşturma potansiyeli nedeniyle sessiz mastoidit tanısı akılda tutulmalıdır. Şüphelenilen olgularda temporal kemiğin BT incelemesi ve sintigrafik incelenme ile tanı doğrulanmalı ve en kısa sürede tedavi edilmelidir.

\section{Çıkar çatışması / finansal destek beyanı}

Bu yazıdaki hiçbir yazarın herhangi bir çıkar çatışması yoktur. Yazının herhangi bir finansal desteği yoktur

\section{Kaynakça}

1. Tsai TC, Yu PM, Tang RB, Wang HK, Chang KC. Otorrhea as a sign of medical treatment failure in acute otitis media: two cases with silent mastoiditis complicated with facial palsy. Pediatrics \& Neonatology 2013; 54:335-38.

2. Martin-HirschDP, Habashi S, Page R, Hinton AE. Latent mastoiditis: no room for complacency. The Journal of Laryngology \& Otology 1991; 105: 767-68.

3. Şahin B, Karavuş A, Şapçı T, Akbulut UG. İntrakranyal komplikasyonlarla seyreden silent mastoidit: olgu sunumu. Turk Arch Otolaryngol 2003; 41: 232-38.

4. Voudouris C, Psarommatis I, Nikas I, Kafouris D, Chrysouli K. Pediatric masked mastoiditis associated with multiple intracranial complications. Case Rep Otolaryngol 2015: 1-4

5. Toprak M, Yener M. Subakut veya Sessiz Mastoidit. In: Dış ve Orta Kulak Cerrahisi, Devranoglu i (ed). 1st ed. İstanbul: Deomed; 2011: 119-20

6. Akyıldız N. Kulak hastalıkları ve mikrocerrahisi. Bölüm 5. Ankara: Bilimsel Tıp Yayınevi 1998; 332-34.

7. Tovi F, Gatot A. Bone scan diagnosis of masked mastoiditis. Ann Otol Rhinol Laryngol 1992; 101: 707-9. 